\title{
Frost-Heaved Bedrock Features: A Valuable Permafrost
}

Indicator

\author{
Les édifices d'éjection gélivale: un bon indice de la présence de \\ pergélisol

\section{Frostgehobene Muttergesteins Formen: ein wertvolles} \\ Dauerfrost Zeichen
}

\section{Jean-Claude Dionne}

Volume 37, numéro 3, 1983

URI : https://id.erudit.org/iderudit/032521ar

DOI : https://doi.org/10.7202/032521ar

Aller au sommaire du numéro

\section{Éditeur(s)}

Les Presses de l'Université de Montréal

\section{ISSN}

0705-7199 (imprimé)

1492-143X (numérique)

\section{Découvrir la revue}

\section{Citer cet article}

Dionne, J.-C. (1983). Frost-Heaved Bedrock Features: A Valuable Permafrost Indicator. Géographie physique et Quaternaire, 37(3), 241-251.

https://doi.org/10.7202/032521ar
Résumé de l'article

Les édifices rocheux d'éjection sont des formes périglaciaires résultant du déplacement vertical de fragments du substrat rocheux. Les fragments produits par gélifraction au droit des fissures et des diaclases sont poussés au-dessus de la surface environnante par l'action du froid. Signalés dès la fin du XIX ${ }^{\mathrm{e}}$ siècle, ils n'ont été décrits et étudiés convenablement que récemment. Ils sont fréquents dans l'hémisphère nord, en particulier au Canada, au Groenland et au Spitsberg. On les trouve dans les principaux types de roches affectés de réseaux de diaclases. Les blocs éjectés montrent souvent des parois altérées et couvertes de lichens crustacés; mais les blocs récemment soulevés montrent à leur base une étroite bande peu altérée et non encore couverte de lichens. Le soulèvement des fragments est lié à l'action du froid, notamment à la gélifraction, la gélidisjonction et aux pressions causées par le gel de l'eau dans les fissures. Les formes actives et non actives se rencontrent dans des régions où le pergélisol existe. Le site le plus méridional connu est celui des monts Groulx, au Québec ( $51^{\circ} 45^{\prime} \mathrm{N}$, alt. $\left.100 \mathrm{~m}\right)$. La température moyenne annuelle de l'air des régions où ces formes sont les mieux développées va de $-4^{\circ}$ à $-10^{0} \mathrm{C}$, avec un nombre de jours de gel annuel compris entre 178 et 300 . Dans tous les sites, la couverture de neige est mince ou absente. Compte tenu des données climatiques et de la répartition géographique des édifices d'éjection, on estime qu'ils indiquent la présence de pergélisol, les formes reliques observées hors des régions à pergélisol témoigneraient donc de l'existence préalable de pergélisol.
Tous droits réservés @ C Les Presses de l'Université de Montréal, 1983
Ce document est protégé par la loi sur le droit d'auteur. L'utilisation des services d'Érudit (y compris la reproduction) est assujettie à sa politique d'utilisation que vous pouvez consulter en ligne.

https://apropos.erudit.org/fr/usagers/politique-dutilisation/ 


\section{FROST-HEAVED BEDROCK FEATURES: A VALUABLE PERMAFROST INDICATOR}

Jean-Claude DIONNE, Département de géographie et Centre d'études nordiques, université Laval, Sainte-Foy, Québec G1K 7P4.

ABSTRACT Frost-heaved bedrock features are periglacial forms produced by the vertical displacement of bedrock fragments. Blocks, frost-wedged from bare bedrock along joints, are raised above the general surface by heave. Although mentioned in the literature of the late 19th century, they have been described and studied in detail only recently. They are widespread in the northern hemisphere, notably in Canada, Greenland and Spitsbergen, where they develop in lithologies with well-developed systems of joints. Commonly, heaved blocks exhibit weathered and lichencovered surfaces except at their base where freshly exposed rock indicates recent heaving. They result from frost processes, particularly from wedging and heaving due to pressure of the freezing of free-water in joints. Active and most non-active features are located in permafrost regions. The southermost occurrence in the northern hemisphere is the Groulx Mountains, in Québec $\left(51^{\circ} 45^{\prime} \mathrm{N}\right.$, alt. $\left.1000 \mathrm{~m}\right)$. The mean annual air temperature for the area of bestdeveloped features ranges from $-4^{\circ}$ to $-10^{\circ} \mathrm{C}$, with the number of days of frost ranging from 178 to 300 . A thin snow cover is common to most sites. Based on climatic data and on the geographical distribution of frost-heaved bedrock features, it is suggested that permafrost occurrence is obvious. Relict features found outside the present-day permafrost zones should indicate former permafrost conditions.
RÉSUMÉ Les édifices d'éjection gélivale: un bon indice de la présence de pergélisol. Les édifices rocheux d'éjection sont des formes périglaciaires résultant du déplacement vertical de fragments du substrat rocheux. Les fragments produits par gélifraction au droit des fissures et des diaclases sont poussés au-dessus de la surface environnante par l'action du froid. Signalés dès la fin du XIX ${ }^{e}$ siècle, ils n'ont été décrits et étudiés convenablement que récemment. Ils sont fréquents dans l'hémisphère nord, en particulier au Canada, au Groenland et au Spitsberg. On les trouve dans les principaux types de roches affectés de réseaux de diaclases. Les blocs éjectés montrent souvent des parois altérées et couvertes de lichens crustacés; mais les blocs récemment soulevés montrent à leur base une étroite bande peu altérée et non encore couverte de lichens. Le soulèvement des fragments est lié à l'action du froid, notamment à la gélifraction, la gélidisjonction et aux pressions causées par le gel de l'eau dans les fissures. Les formes actives et non actives se rencontrent dans des régions où le pergélisol existe. Le site le plus méridional connu est celui des monts Groulx, au Québec $\left(51^{\circ} 45^{\prime} \mathrm{N}\right.$, alt. $100 \mathrm{~m})$. La température moyenne annuelle de l'air des régions où ces formes sont les mieux développées va de $-4^{\circ}$ à $-10^{\circ} \mathrm{C}$, avec un nombre de jours de gel annuel compris entre 178 et 300 . Dans tous les sites, la couverture de neige est mince ou absente. Compte tenu des données climatiques et de la répartition géographique des édifices d'éjection, on estime qu'ils indiquent la présence de pergélisol, les formes reliques observées hors des régions à pergélisol témoigneraient donc de l'existence préalable de pergélisol.
ZUSAMMENFASSUNG Frostgehobene Muttergesteins Formen: ein wertvolles Dauerfrost Zeichen. Frostgehobene Muttergesteins Vorgänge sind periglaziale Formen die durch die vertikale Verschiebung von Muttergesteins Fragmenten entstehen. Blöcke, vom nackten Muttergestein durch Eiskeile an Fugen entlang gelöst, werden über die allgemeine Oberfläche durch Frosthebung erhoben. Wenn auch schon im späten 19. Jahrhundert erwähnt, wurden sie erst kürzlich beschrieben und erforscht. Sie sind in der nördlichen Hemisphäre häufig, besonders in Kanada, Grönland und Spitzbergen, wo sie an Küsten mit gut entwickelten Fugensystemen entstehen. Meistens zeigen gehobene Blöcke verwitterte und Moosbedeckte Oberflächen, mit Ausnahme der Basis, wo erst vor kurzem blossgelegtes Gestein auf neuere Hebungen hindeutet. Sie bilden sich durch Frostvorgänge, besonders durch Verkeilen und Heben, dass besonders durch den Druck des gefrierenden, freien Wassers in den Fugen bewirkt wird. Die tätigen und auch die meisten untätigen Formen befinden sich in Dauerfrost Gegenden. Das südlichste Vorkommen in der nördlichen Hemisphäre liegt in den Groulx Bergen in Québec (514 $45^{\prime} \mathrm{N}$, Hohe1000 m). Die jährliche Durchschnitts Temperatur der Luft in der Gegend mit den am besten entwickelten Formen beträgt zwischen $-4^{\circ}$; und $-10^{\circ} \mathrm{C}$, mit der Zahl der Frosttage zwischen 178 und 300 schwingend. In den meisten Orten findet man gar keine oder nur eine dünne Schneedecke. Auf Grund klimatischer Daten und der allgemeinen geographischen Verteilung von frostgehobenen Muttergesteins Formen, kann man annehmen, dass das Vorkommen von Dauerfrost sicher ist. Relikien Formen, die man ausserhalb der jetzigen Dauerfrost Zonen findet, deuten auf ehemalige Dauerfrostverhältnisse hin. 


\section{INTRODUCTION}

According to BLACK (1976) only a few geomorphic features are considered as diagnostic indicators of former permafrost. The best recognized of these are pingos and ice-wedge casts. However, other features such as palsas, rock glaciers, large sorted polygons and circles, cryoplanation terraces and thermokarst features are also used commonly by several authors (WASHBURN, 1976, 1979) to infer present or former permafrost conditions.

Frost-heaved bedrock features are periglacial forms produced by the vertical displacement of bedrock fragments. Blocks, frost-wedged from bare bedrock along joints, are raised above the general surface by frost processes, particularly ice lensing or freezing of freewater in joints. They were first reported in the late 19th century (TYRRELL, 1897) and have since been observed and described in several localities by a number of authors (Table I). They have been used only recently to infer permafrost conditions (DIONNE, 1981). This paper presents the most recent data on frost-heaved features, discusses some climatic parameters and suggests that these periglacial forms could be considered as a valuable permafrost indicator.

\section{GEOGRAPHICAL DISTRIBUTION}

Frost-heaved bedrock features have been reported from cold regions of both hemispheres but particularly in the northern hemisphere (Table I and Fig. 1). To our knowledge, the first mention was made by TYRRELL (1897, p. 84) who reported frost-heaved blocks in diabase and quartzite from the area of Dawson Inlet and of Churchill, western Hudson Bay (Canada) respectively. A brief description of frost-heaved features in diabase occurring in Sassen Bay area, Spitsbergen, is given by HÖGBOM (1910, p. 41-44; 1914, p. 274-277). However, frost-heaved bedrock features were only properly described and explained many decades after these two early papers. YARDLEY (1951) reported "frost-thrust blocks" from Indin Lake, Northwest Territories (Canada), occurring both in basic volcanic rocks and in quartzmica schists. At about the same time, KRANCK (1951, p. 37-38) briefly mentioned similar features in basalt from the Inoucdjouac area (Hopewell Sound), eastern Hudson Bay (Québec).

More recently, various frost-heaved bedrock features were reported from several areas and have been more thouroughly described and explained. Such features occur in Greenland (MALAURIE, 1968; WASHBURN, 1969); Arctic and Subarctic Canada (KERR, 1977; DILABIO, 1978 and 1982; DYKE, 1979 and 1981; FRENCH and GILBERT, 1982) and particularly from northern Québec (BOURNÉRIAS, 1972; PAYETTE, 1978; DIONNE, 1978 and 1981; GANGLOFF et al., 1976; GODARD, 1979 ; HILLAIRE-MARCEL, 1979 ; LAVERDIĖRE and GUIMONT, 1981; LAURIOL et al., 1982). In addition, two sites of frost-heaved bedrock features were reported from the southern hemisphere: South Shetland Islands (THOM, 1978) and Tasmania (CAINE, 1983).

It appears from the recent literature that frost-heaved bedrock features are more common and widespread than had been thought previously, and that these periglacial forms need to be better known. According to Black (1983, personal communication), similar features also occur in temperate regions and can be related either to seasonal frost action, tectonics and isostatic rebound. Black mentioned having seen some active heaved-bedrock features in southern Sweden. However, as nothing has been published yet about these original features, they are not discussed in this paper.

\section{CHARACTERISTICS OF FROST-HEAVED BEDROCK FEATURES}

The various frost-heaved bedrock features that have been described to date vary considerably in form, shape and size. The most elementary form, the so-called "monolith", is a single angular fragment raised above the surrounding surface (Fig. 2). Complex forms consist of a cluster of angular fragments forming conical and rounded mounds up to $3 \mathrm{~m}$ high and $20 \mathrm{~m}$ in diameter, and also of ridges up to $1 \mathrm{~m}$ high, $5 \mathrm{~m}$ wide and 30-40 m long. Although all features result from frost heaving caused for the most part by the freezing of free-water in joints or by ice lensing, often related to hydrostatic pressure, there are differences due to variations in terrain conditions: humidity, exposition, Iithology, structure of bedrock and pattern of joints. In virtually all frost-heaved structures, cavities of various sizes occur under heaved blocks. These cavities are partly or entirely filled with water in summer and with ice in winter. Usually, there is no matrix of fines in the open fissures and cavities, except locally where a small quantity of debris may have been washed from the surface (DIONNE, 1981).

The angular fragments vary in size from place to place depending upon the lithology and the pattern of joints. Size ranges from a few decimetres to a few metres. For example, at Lac Guillaume-Delisle (Richmond Gulf, Québec), angular fragments in dolostone measuring $5 \times 7 \mathrm{~m}$ and heaved $2 \mathrm{~m}$ above the surrounding surface have been observed (Fig. 4). At the same locality, two large frost-heaved mounds were composed respectively of 84 and 91 angular fragments of various sizes (Fig. 5). More commonly, however, frost-heaved mounds include 10 to 35 angular fragments. Recently heaved fragments generally show at their base a narrow strip of lichen-free and non-weathered rock surface.

Frost-heaved bedrock features can be grouped into four major geomorphic categories:

a) Primary or elementary structures. These are composed of one or a handful of fragments (generally less than 5), which are raised a few decimetres (usually less than $1 \mathrm{~m}$ ), above the surrounding surface. This is 
TABLE I

Known occurrences of frost-heaved bedrock features throughout the world

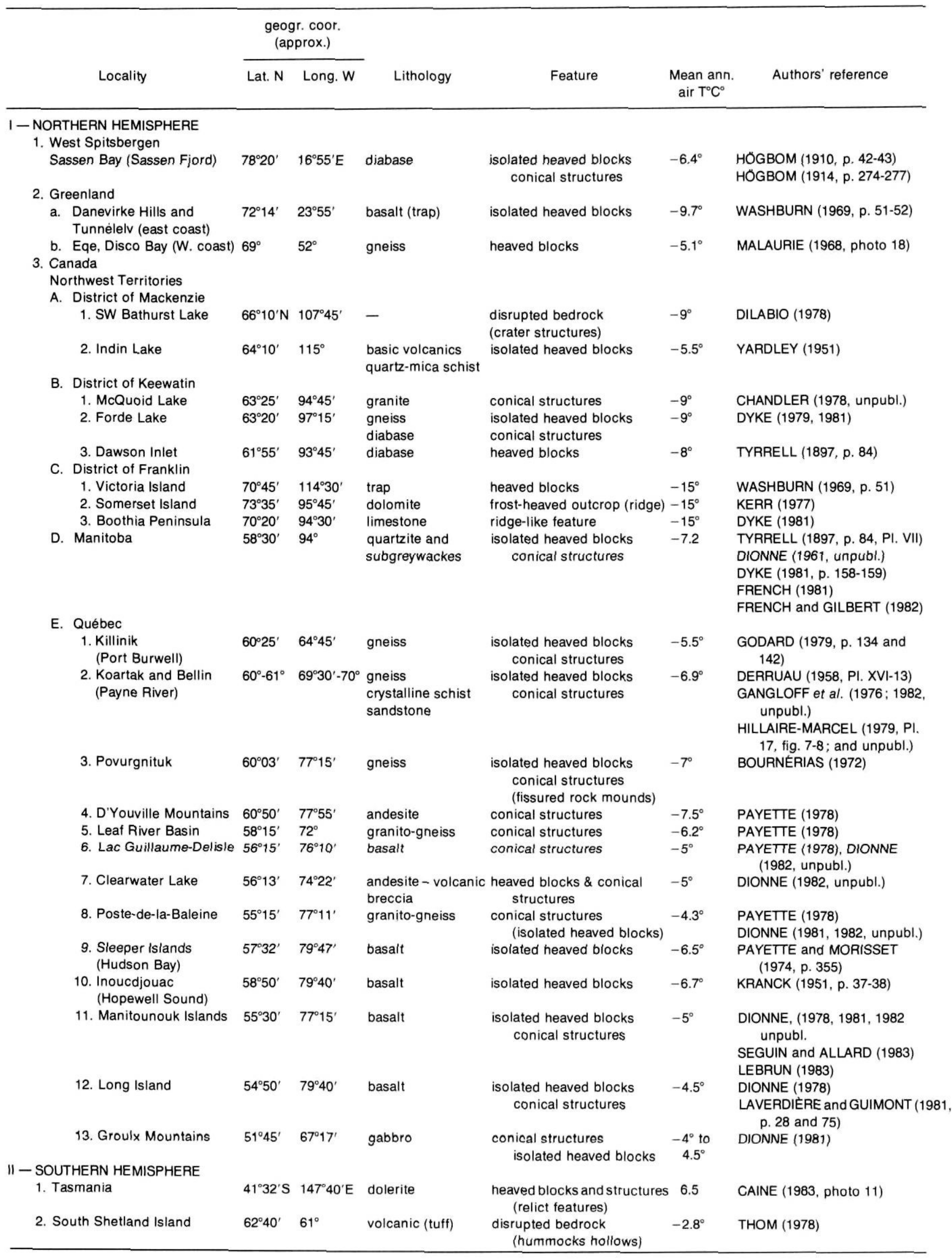




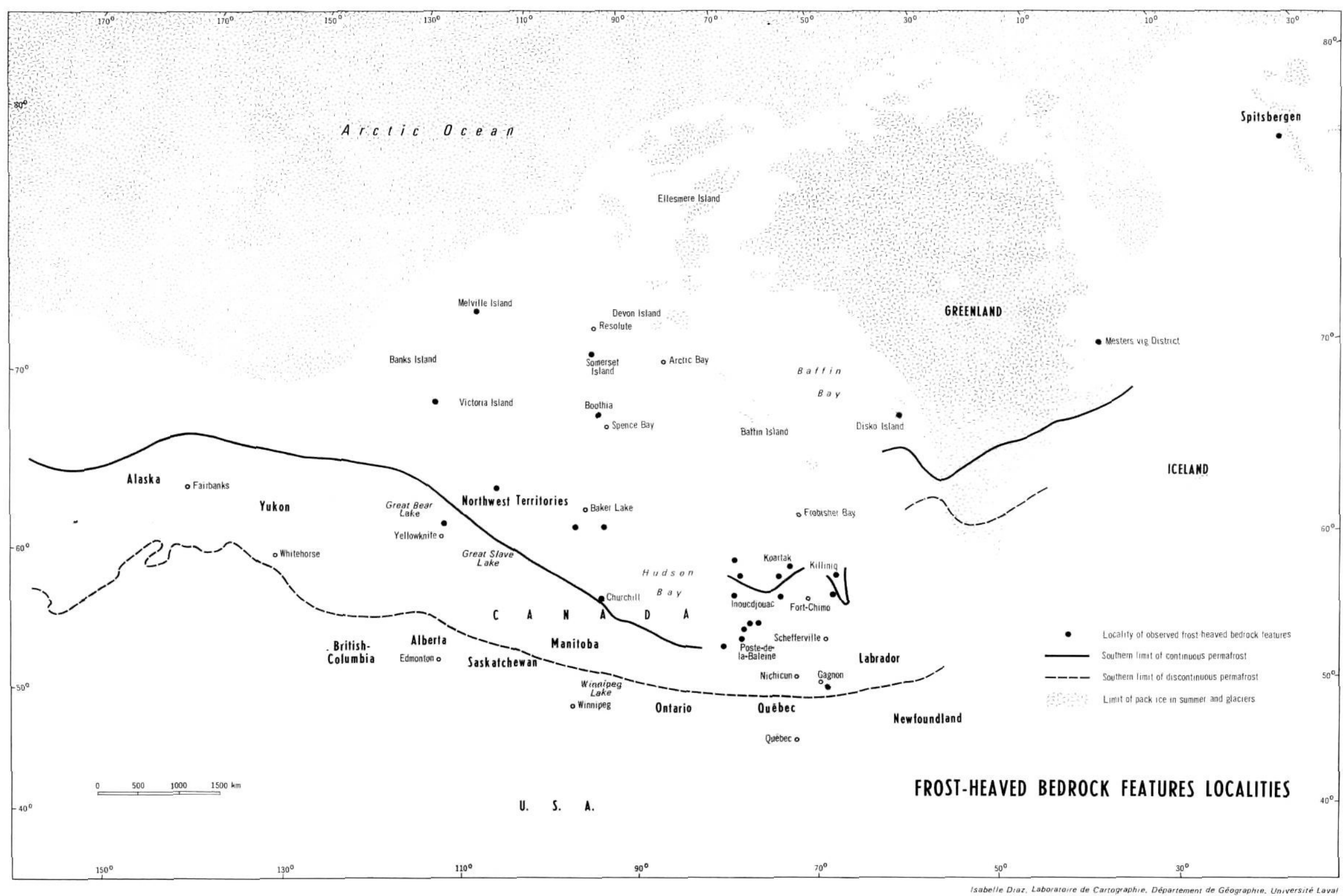

FIGURE 1. Frost-heaved bedrock features localities. Les sites des édifices rocheux d'éjection. 
the more common frost-heaved bedrock feature (Fig. 2-3).

b) Conical and rounded mounds. These are formed by a cluster of several angular fragments raised vertically above the surrounding surface and commonly thrusted to various degrees (Fig. 4-8). They have a cauliflower or a mushroom-like appearance. Depending upon the degree of evolution, some structures are characterized by a central depression, others by a surrounding depression, sometimes filled with water, and others by a major, centrally located open fissure up to $1 \mathrm{~m}$ wide along which angular fragments are disposed vertically or have been thrusted. Subsequently to heaving, large angular fragments are commonly shattered into smaller
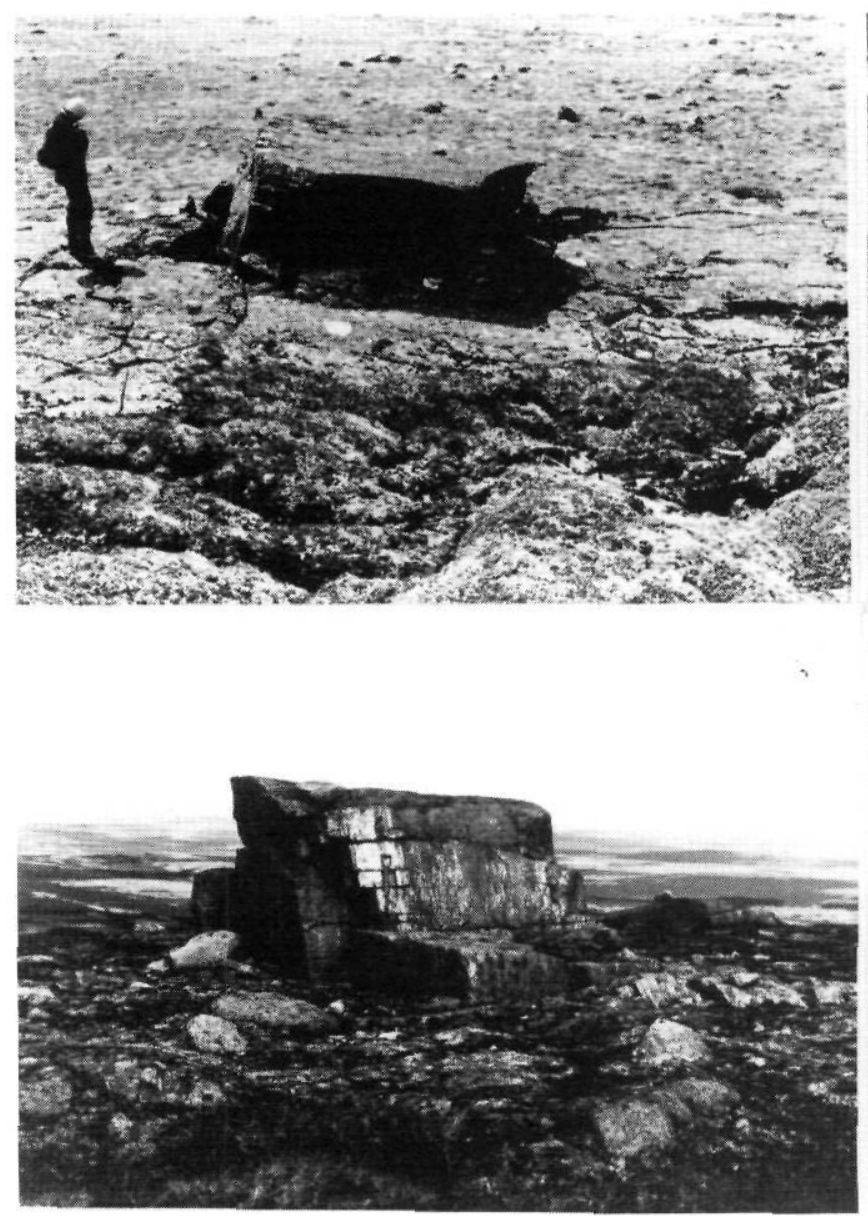

FIGURE 2. A large frost-heaved block of basalt projecting through a glacially polished and sculptured bedrock surface, at Lac Guillaume-Delisle (Richmond Gulf) $\left(56^{\circ} \mathrm{N}\right)$, subarctic Québec. Vertical displacement is approximately $125 \mathrm{~cm}(8.7 .82)$. Méga-bloc de basalte soulevé par le froid, d'environ $125 \mathrm{~cm}$ au-dessus de la surface glaciaire environnante, au lac Guillaume-Delisle, Québec subarctique (7.8.82).

FIGURE 3. A massive frost-heaved feature in crystalline rocks at the summit of Groulx Mountains $\left(51^{\circ} 45^{\prime} \mathrm{N}\right.$, alt. $\left.1000 \mathrm{~m}\right)$, central Québec. The maximum displacement is approximately $200 \mathrm{~cm}(7.24 .80)$.

Édifice d'éjection massif dans roche cristalline, au sommet des monts Groulx (51⒋ $45^{\prime} \mathrm{N}$, alt. $100 \mathrm{~m}$ ), au Québec central. Soulèvement maximal d'environ $200 \mathrm{~cm}$ (24.7.80). pieces by frost action. A slightly different type of feature results (Fig. 9).

c) Ridge structures. These are formed along major fracture zones or along the edge of elongated bedrock outcrops. They are approximately one metre high, a few metres wide and up to $50 \mathrm{~m}$ long. They occur most commonly in layered sedimentary rocks but are also observed in sheeted crystalline rocks (Fig. 10).

d) Domed structures. These are formed by the doming of layered bedrock (generally sedimentary formations). The doming ranges from a few decimetres to as much as $1 \mathrm{~m}$ in height (Fig. 11). In this type of feature, the fragments are only slightly thrusted or distorted rather
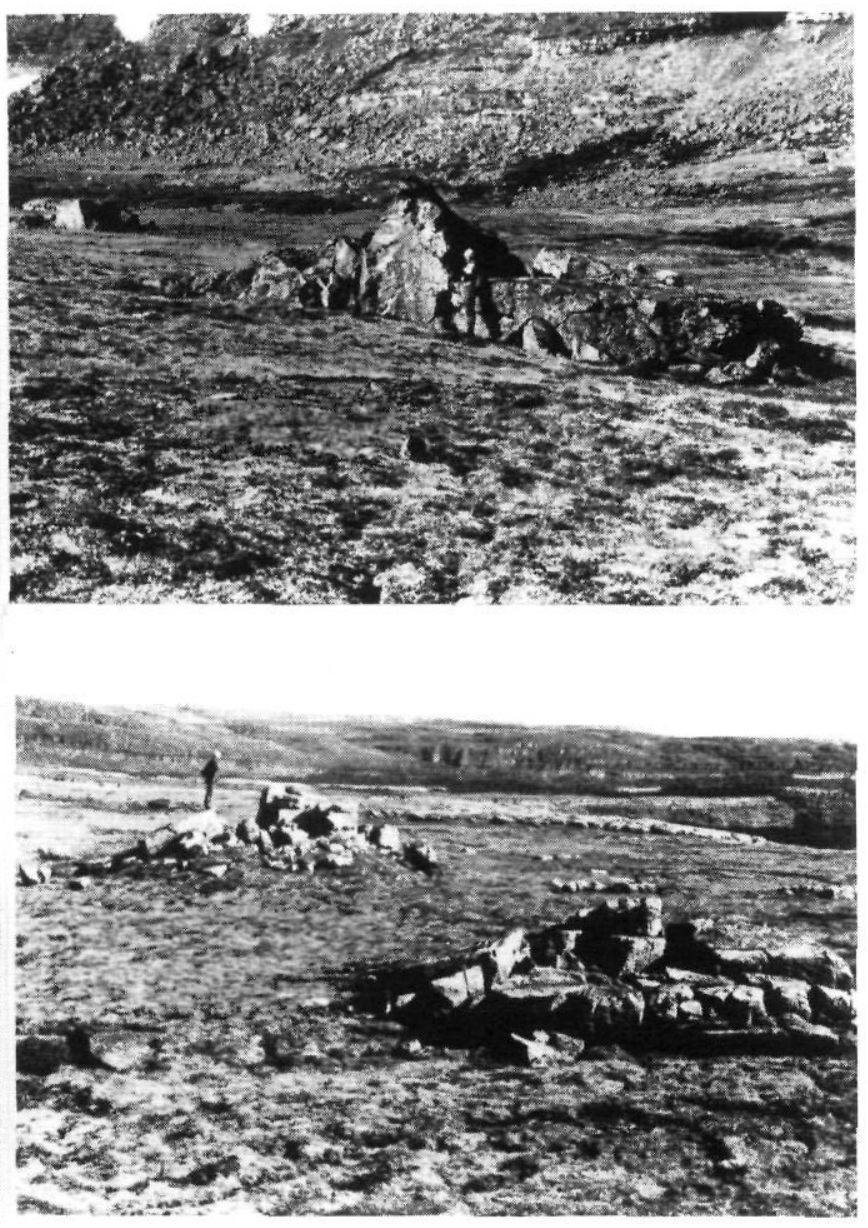

FIGURE 4. Large frost-heaved blocks in dolostone at Lac Guillaume-Delisle; the large flat block (at right) is $3.5 \times 4 \mathrm{~m}$ and is up to $125 \mathrm{~cm}$ vertically displaced (8.7.82).

Méga-blocs de dolomie soulevés par le froid, au lac GuillaumeDelisle, la grande dalle horizontale, à droite, mesure 3,5 $\times 4 \mathrm{~m}$ et a été soulevée d'environ $125 \mathrm{~cm}$ (7.8.82).

FIGURE 5. Two large frost-heaved bedrock features in dolostone, at Lac Guillaume-Delisle (8.7.82).

Deux gros édifices d'éjection dans dolomie, au lac GuillaumeDelisle (7.8.82). 
than having been heaved vertically. The doming usually results from ice lensing related to hydrostatic head. It is probably an initial stage of the second category.

Frost-heaved bedrock structures have been observed in volcanic, igneous, metamorphic and sedimentary rocks (Table II). However, all types of rock generally show a well-developed pattern of joints and fissures of primary origin as in basalt or of secondary origin as in granite and sandstone. Stratification and sheeting seem to be favorable factors for frost-heaving in certain types of rock.
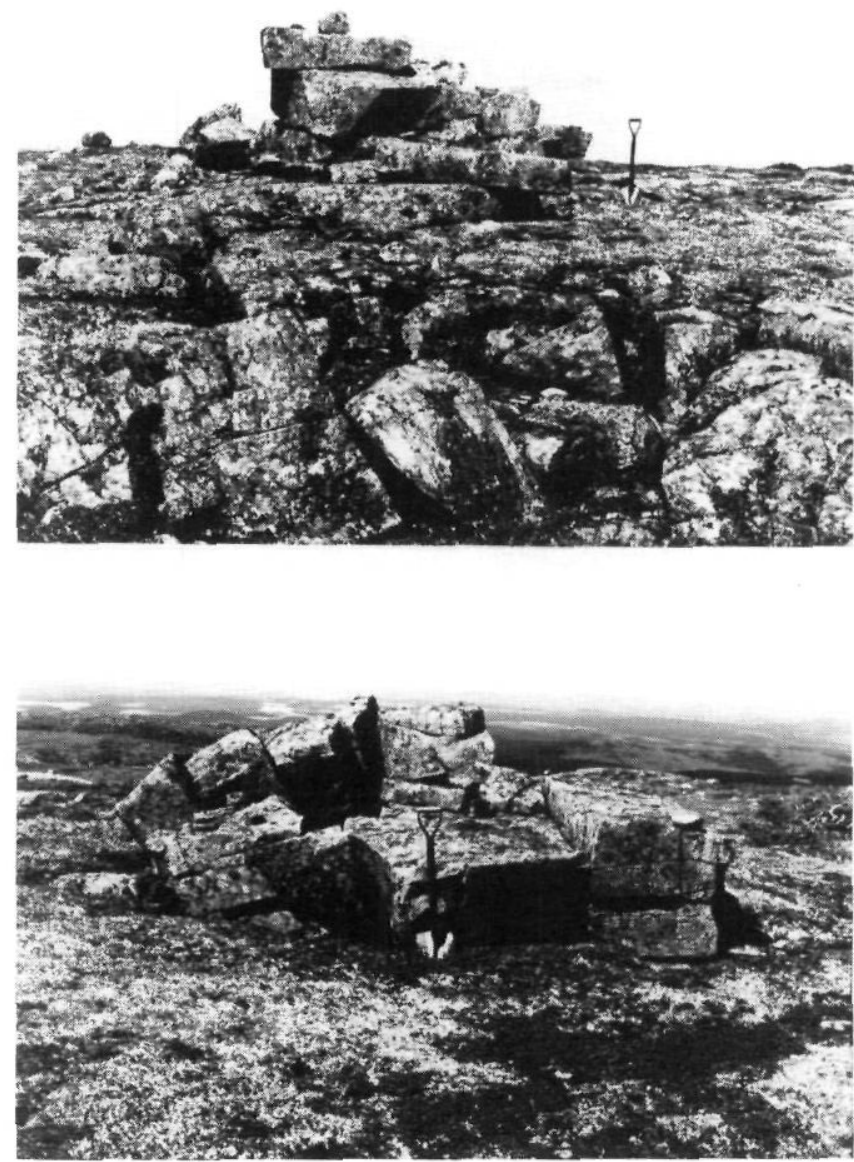

FIGURE 6. A common frost-heaved bedrock feature in gabbro, made up of several large angular fragments, in Groulx Mountains. Note the perched glacial boulder at the top of feature $(7.24 .80)$

Édifice de soulèvement gélival typique dans des gabbros, formé de plusieurs gros fragments anguleux, au sommet des monts Groulx. À remarquer le bloc glaciaire perché au sommet de l'édifice (24.7.80).

FIGURE 7. A medium-size frost-heaved conical feature, about $2 \mathrm{~m}$ high, in crystalline rocks, showing a few fragments slightly thrusted, in Groulx Mountains (7.24.80).

Edifice d'éjection de forme cônique et de taille moyenne, d'environ $2 \mathrm{~m}$ de haut, dans des roches cristallines montrant quelques blocs légèrement basculés, au sommet des monts Groulx (24.7.80).
TABLE ॥

Lithologies in frost-heaved bedrock features

\begin{tabular}{|c|c|c|c|}
\hline Volcanic & Igneous & Metamorphic & Sedimentary \\
\hline Andesite & Dolerite & crystalline schists & Dolomite \\
\hline Basalt & Gabbro & quartz-mica schists & Greywacke \\
\hline Breccia & Granite & gneiss & Limestone \\
\hline Diabase & & granito-gneiss & Sandstone \\
\hline Trapp & & Quartzite & \\
\hline
\end{tabular}
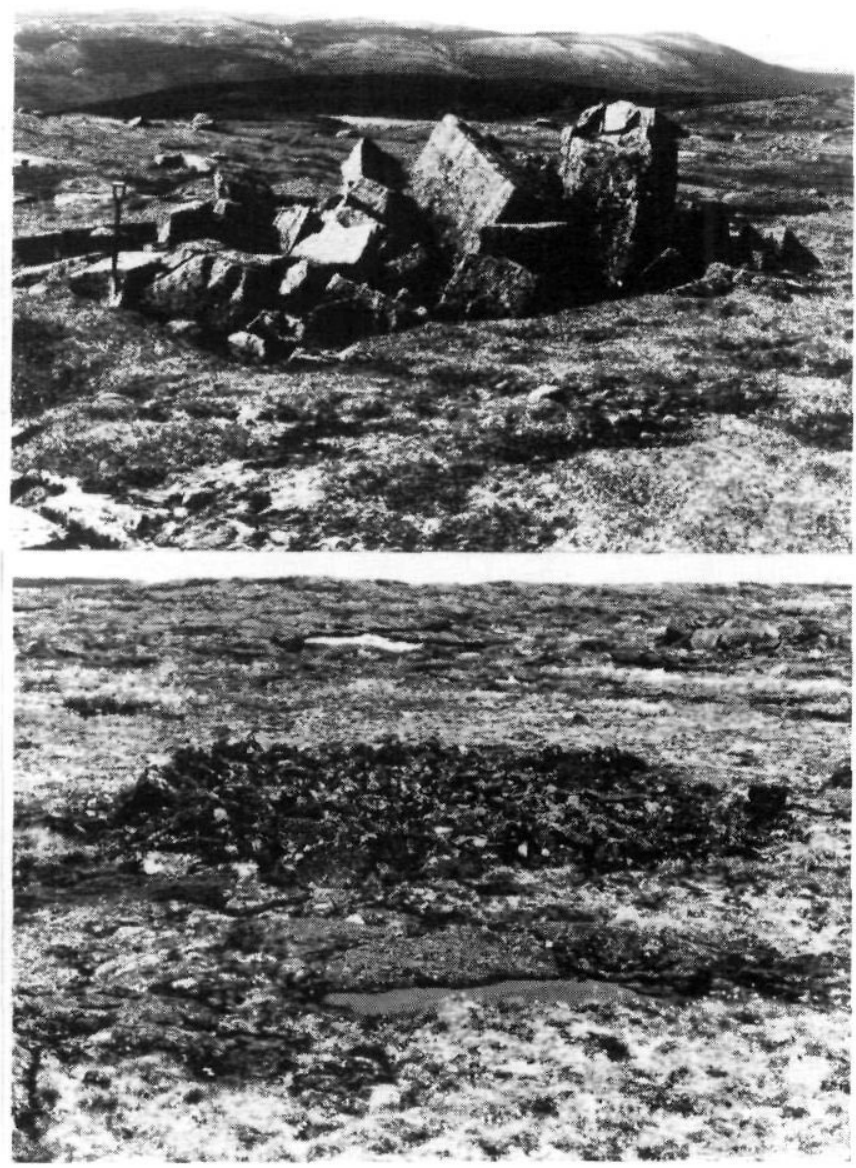

FIGURE 8. A frost-heaved bedrock feature in which most fragments are thrusted; in a gabbroic bedrock, in Groulx Mountains. The shovel is $90 \mathrm{~cm}$ long (7.24.80).

Édifice d'éjection composé principalement de fragments basculés, dans du gabbro, au sommet des monts Groulx. La pelle mesure $90 \mathrm{~cm}$ de long (24.7.80).

FIGURE 9. A frost-heaved bedrock feature, $12 \mathrm{~m}$ in diameter, in which the uplifted fragments have been subsequently frost-shattered and reduced into many smaller pieces, in basalt, at Manitounuk Islands, subarctic Québec (7.14.82).

Édifice d'éjection et de gélifraction, de $12 \mathrm{~m}$ de diamètre, dans du basalte, aux îles Manitounouc, Québec subarctique (14.7.82). 


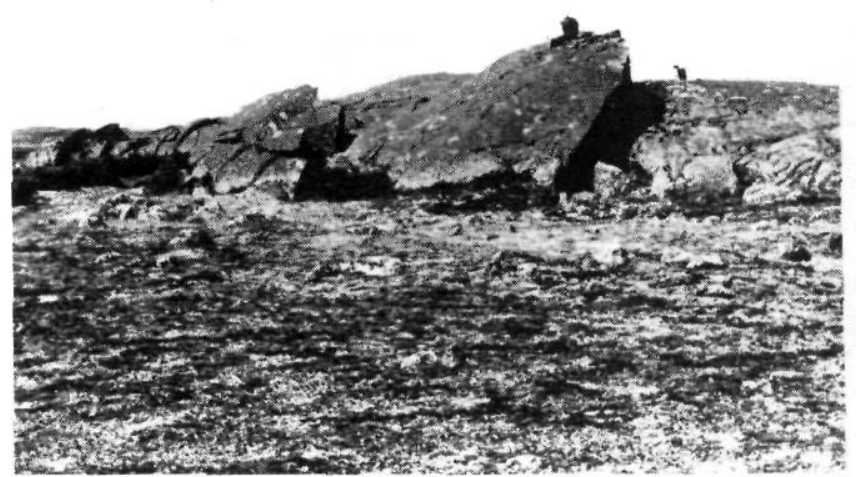

FIGURE 10. A ridge-like frost-heaved feature in basalt, occurring along an elongated glacially sculptured outcrop, at Lac Guillaume-Delisle. The largest fragment is $6.5 \times 7 \times 13 \mathrm{~m}$, and shows a maximum vertical displacement of $150 \mathrm{~cm}$ (8.7.82).

Crête de soulèvement gélival dans du basalte au lac GuillaumeDelisle, développée au droit d'une colline rocheuse à modelé glaciaire. Le plus gros fragment mesure $6,5 \times 7 \times 13 \mathrm{~m}$ et a été soulevé d'environ $150 \mathrm{~cm}$ (7.8.82).

Field observations indicate that frost-heaved bedrock features occur in a large variety of topographic conditions, i.e. on nearly horizontal surfaces, on gently sloping surfaces and even on slopes up to 15-20 degrees. However, most sites are found on gently sloping surfaces of less than 5 degrees. Conical mounds made up of a cluster of fragments are commonly found around shallow, poorly drained depressions in the bedrock surface into which water tends to collect and where the water table is close to the surface. The largest structures observed in subarctic Québec occurred in such an environment (PAYETTE, 1978; Dionne, 1982, unpubl.). The presence of water is prerequisite for the development of single block and mound structures because the upward displacement results from the freezing of free-water in joints and particularly in horizontal planes or in cavities under rock fragments. In most cases, the only water available is that from snowmelt and rain. Free-water draining into shallow depressions fills joints, fissures and cavities in bedrock and is introduced between horizontal strata and sheeting planes. During the winter, this water freezes and forms ice masses, the main cause of frost-wedging and heaving. In most sites, the bedrock surface is commonly bare and well exposed, but locally it may be covered by a thin sheet of till $(15-20 \mathrm{~cm}$ thick) or of organic debris (usually less than $30 \mathrm{~cm}$ in thickness).

\section{DISTRIBUTION OF PERMAFROST IN CANADA}

Depending on ground conditions (BROWN, 1969), the southern margin of the continuous permafrost zone in Canada, according to most authors, follows closely the mean annual air temperature isotherm of $-7^{\circ}$ to $-8^{\circ} \mathrm{C}$, while the southern limit of the discontinuous permafrost zone is close to the mean annual isotherm $-1^{\circ}$ to $-2^{\circ}$

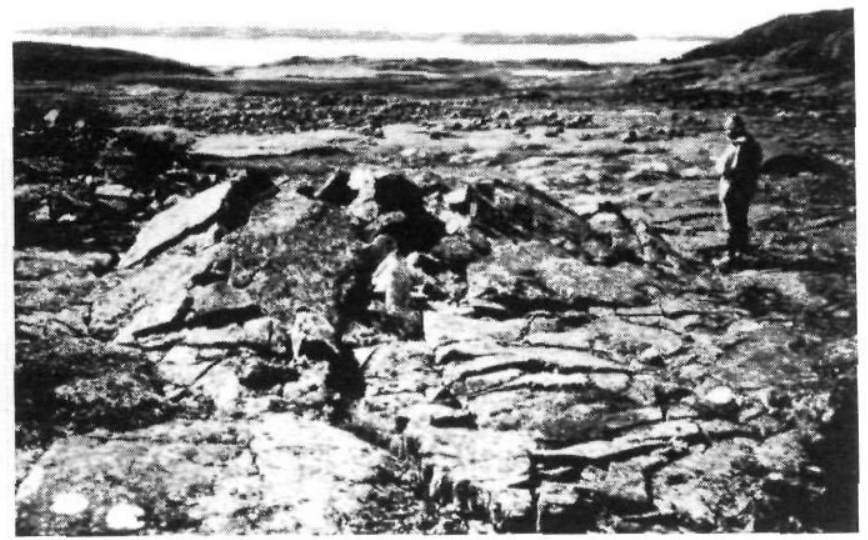

FIGURE 11. A dome-like frost-heaved feature in basalt, about $8 \mathrm{~m}$ in diameter and $100 \mathrm{~cm}$ high, at Lac Guillaume-Delisle (8.7.82). (Photo: Linda Dion.)

Structure de soulèvement en dôme dans du basalte, d'environ $8 \mathrm{~m}$ de diamètre et $100 \mathrm{~cm}$ de haut, au lac Guillaume-Delisle (7.8.82). (Photo : Linda Dion.)

(BROWN and PÉWÉ, 1973; BROWN, 1978). However, a few scattered patches of permafrost do occur in peatland in areas with a mean annual air temperature close to or slightly above $0^{\circ} \mathrm{C}$ (ZOLTAI, 1971, 1972; BROWN, 1973).

In Québec-Labrador, permafrost is generally not found south of the $-1^{\circ} \mathrm{C}$ mean annual air temperature isotherm, while between the $-1^{\circ}$ to $-4^{\circ}$ isotherms permafrost is patchy and is restricted to certain types of terrain, mainly peatland. North of the $-4^{\circ}$ isothern, permafrost is widespread, while continuous permafrost occurs only north of the $-6.5^{\circ}$ to $-7^{\circ}$ isotherms (BROWN, 1979; IVES, 1979). A few occurrences of permafrost, however, have been observed or measured in peatland terrain south of the $-1^{\circ}$ isotherm and appear to be largely relict or related to very local conditions (BROWN, 1975; DIONNE, 1978, 1980).

\section{RELATION OF FROST-HEAVED BEDROCK FEATURES WITH PERMAFROST}

As far as is known, in North America, heaved-bedrock features occur exclusively within the permafrost zones as mapped by BROWN (1978). In north-central Canada, most sites reported $(90-95 \%)$ are within the continuous permafrost zone, while in Québec, about $65 \%$ of the sites are in the discontinuous permafrost zone.

Almost all sites of well-developed frost-heaved bedrock features have a mean annual air temperature ranging from $-4^{\circ}$ to $-10^{\circ} \mathrm{C}$. Consequently, it appears that such features are mainly concentrated within the northern half of the discontinuous permafrost zone and the southern part of the continuous permafrost zone. In northern Canada, the best developed frost-heaved features occur near Churchill (Manitoba), Indin and 
Bathurst Lakes (District of MacKenzie), and near McQuoid and Forde Lakes (District of Keewatin) (DYKE, 1981). The mean annual air temperatures for these sites are respectively $-7.2^{\circ},-5.6^{\circ}$, and $-9^{\circ}$ (Table II). In northern Québec, good examples of frost-heaved structures are found as far south as the Manicouagan massif $\left(51^{\circ} 45^{\prime} \mathrm{N}\right.$ at $1,000 \mathrm{~m}$ altitude), and farther north at Postede-la-Baleine, Manitounouc Islands, Lac GuillaumeDelisle, Povurgnituk, Rivière aux Feuilles Basin, Youville Mountains, Koartak and Killiniq (Port Burwell). The mean annual air temperatures at these localities range from $-4^{\circ}$ to $-7^{\circ} \mathrm{C}$. Most sites are within the discontinuous permafrost zone where the snow cover is thin or nearly absent. Only the most northern sites in Québec (Killiniq, Koartak and Youville Mountains) are within the continuous permafrost zone.

The mean temperature of the coldest month for all the sites reported in Canada (including Québec) ranges from $-21.7^{\circ}$ (Koartak) to $-34.9^{\circ} \mathrm{C}$ (Spence Bay), while the mean temperature for the warmest month ranges from $5.7^{\circ}$ (Koartak) to $16^{\circ}$ (Yellowknife). In northern Canada, the number of days with frost ranges from 229 (Yellowknife) to 305 (Arctic Bay) with a median of 255 (Churchill). In northern Québec, areas with frostheaved bedrock features have 243 (Poste-de-la-Baleine) to 262 (Koartak) mean annual days of frost.

Similar temperature conditions are found elsewhere. In Greenland and Spitsbergen, the mean annual air temperatures for the sites of frost-heaved bedrock fea- tures are $-5.1^{\circ}$ (Disco Bay), $-9.7^{\circ}$ (Mesters vig District), and $-6.4^{\circ}$ (Sassen Fiord). In the South Shetland Islands, the disrupted bedrock features reported by THOM (1978) occur in a discontinuous permafrost zone with a mean annual air temperature of $-2.8^{\circ}$. However, these frost features differ from the most common types occurring in northern Québec. The relict frost-heaved bedrock features from Tasmania are in an area without permafrost and with a mean annual air temperature of $6.5^{\circ} \mathrm{C}$ (CAINE, 1983, p. 37 ).

The mean annual snowfall in the area of the bestdeveloped frost-heaved features in northern Canada ranges from 80 to $200 \mathrm{~cm}$, while in northern Québec it ranges from 120 to $250 \mathrm{~cm}$ (Table III). Unfortunately, snow cover data are not available for most sites of reported frost-heaved bedrock features. However, it is known that the snow cover is either thin or absent due to strong wind activity in winter. Consequently, wide bare rock surfaces are largely exposed to cold temperatures and frost action.

Freezing and thawing indices have been used recently to determine the relationships of periglacial features and permafrost zones (HARRIS, 1981). Although frostheaved bedrock features are not considered in this study, data suggest that a relatively high freezing index and a relatively low thawing index characterize most sites of frost-heaved bedrock features in Canada. Data for selected stations in north central Canada, an area with well developed frost-heaved features, are given in

TABLE III

Climatic summary for selected stations in northern Canada and Québec ${ }^{1}$

\begin{tabular}{|c|c|c|c|c|c|c|c|}
\hline \multirow[b]{2}{*}{ Locality } & \multirow{2}{*}{$\frac{\text { Mean }}{\begin{array}{c}\text { Annual } \\
\text { Air } \mathrm{T}^{\circ} \mathrm{C}\end{array}}$} & \multicolumn{2}{|c|}{ Mean $\mathrm{T}^{\circ}$ of } & \multirow{2}{*}{$\begin{array}{l}\text { No days } \\
\text { with frost }\end{array}$} & \multirow{2}{*}{$\begin{array}{c}\text { Mean } \\
\text { annual } \\
\text { snowfall } \\
(\mathrm{mm})\end{array}$} & \multirow{2}{*}{$\begin{array}{c}\text { Mean } \\
\text { annual } \\
\text { precipitation } \\
(\mathrm{mm})\end{array}$} & \multirow[b]{2}{*}{$\begin{array}{c}\text { Permafrost } \\
\text { zone }^{2}\end{array}$} \\
\hline & & $\begin{array}{l}\text { Coldest } \\
\text { month }\end{array}$ & $\begin{array}{c}\text { Warmest } \\
\text { month }\end{array}$ & & & & \\
\hline Arctic Bay & -9.9 & -27.0 & 9.7 & 305 & 711 & 125 & $\mathrm{C}$ \\
\hline Baker Lake & -12.3 & -33.6 & 10.7 & 279 & 889 & 213 & C \\
\hline Cambridge Bay & -14.9 & -34.6 & 8.2 & 291 & 726 & 139 & C \\
\hline Churchill & -7.3 & -27.6 & 12.0 & 255 & 1839 & 396 & $\mathrm{C}$ \\
\hline Frobisher & -8.9 & -26.2 & 7.9 & 272 & 2469 & 419 & $\mathrm{C}$ \\
\hline Resolute & -16.4 & -33.5 & 4.3 & 321 & 787 & 153 & $\mathrm{C}$ \\
\hline Spence Bay & -15.4 & -34.6 & 7.1 & 292 & 808 & 136 & $\mathrm{C}$ \\
\hline Yellowknife & -5.6 & -28.6 & 16.0 & 229 & 1094 & 250 & C \\
\hline Port-Chimo (Kuujjuaq) & -5.3 & -23.4 & 11.4 & 253 & 2367 & 484 & $\mathrm{D}$ \\
\hline Inoucdjouac & -6.7 & -24.9 & 8.9 & 262 & 1229 & 356 & $\mathrm{D}$ \\
\hline $\begin{array}{l}\text { Killiniq } \\
\quad \text { (Port Burwell) }\end{array}$ & -5.5 & -20.0 & 5.0 & 240 & 2000 & 400 & $\mathrm{D}$ \\
\hline Koartak & -6.9 & -21.7 & 5.7 & 295 & 1473 & 311 & C \\
\hline Nitchequon & -3.8 & -22.9 & 13.6 & 239 & 2844 & 762 & D \\
\hline Poste-de-la-Baleine & -4.1 & -22.3 & 10.6 & 243 & 2507 & 636 & $\mathrm{D}$ \\
\hline Schefferville & -4.6 & -22.7 & 12.6 & 252 & 3355 & 722 & $\mathrm{D}$ \\
\hline
\end{tabular}

1 Data from Canadian Normals, Environment Canada (1973)

2 According to the Permafrost Map (BROWN, 1978)

$\mathrm{C}=$ Continuous $; \mathrm{D}=$ Discontinuous 
Table IV. Within the area concerned, the freezing index ranges from 3614 to 6050 degree days $\left({ }^{\circ} \mathrm{C}\right)$ and the thawing index ranges from 539 to 1667 degree days. In Québec, the freezing index for the area of frost-heaved bedrock features ranges from 2342 (Gagnon) to 3379 (Inoucdjouac) degree-days $\left({ }^{\circ} \mathrm{C}\right)$, while the thawing indices range from 545 (Koartak) to 1490 (Gagnon) degree-days $\left({ }^{\circ} \mathrm{C}\right)$. Thus, the approximate freezing and thawing indices for the most southerly site of frostheaved bedrock features (Groulx Mountains), based on temperature data at Gagnon, are respectively 2342 and 1490 degree-days $\left({ }^{\circ} \mathrm{C}\right)$.

\section{DISCUSSION}

According to known occurrences, active and recent frost-heaved bedrock features are obvious in permafrost areas; in northern Canada, most localities (90-95\%) are in the continuous permafrost zone with a mean annual air temperature ranging between $-5.6^{\circ}$ (Yellowknife) and $-15^{\circ} \mathrm{C}$ (Spence Bay). In northern Québec, active and recent frost-heaved forms occur both in continuous (35\%) and discontinuous permafrost zones (65\%), with a mean annual air temperature ranging from $-4^{\circ}$ to $-7^{\circ} \mathrm{C}$. In most localities, only a few features really indicate recent or modern activity. Most features are no longer active; some probably developed earlier during the colder periods of the Holocene in northern Québec (PAYETTE, 1980). Similarly at Churchill (Manitoba), the frost-heaved features in quartzite reported by FRENCH and GILBERT (1982) are considered to be largely relict features.

Since active or recent frost-heaved bedrock features are found within the permafrost zones, it is very likely that permafrost conditions greatly favor, or are prerequisite to their development although other factors such as topography, lithology, humidity and absence of forest and snow covers are important controlling factors. Seasonal frost action in areas where permafrost does occur is involved in the development of frost-heaved bedrock features. However, it is not known yet that the features are directly related to permafrost conditions, although active features always occur in present-day permafrost regions. Evidence of recent upward displacement is provided by a lichen-free and nonweathered surface at the base of uplifted angular fragments. Relict features in an area with a mean annual air temperature higher than $0^{\circ} \mathrm{C}$ indicate former permafrost conditions with a mean annual air temperature of at least $-4^{\circ} \mathrm{C}$ or lower. According to FRENCH (1981), frost-heaved bedrock features are representative of very active periglacial regions.

Depending upon the rate of weathering processes, frost-heaved features may survive for many hundreds of years and perhaps even longer. Persistence of forms varies considerably from place to place depending upon lithology and erosional processes. However, it is likely that frost-heaved features such as large heaved blocks
TABLE IV

Freezing and thawing indices (degree days ${ }^{\circ} \mathrm{C}$ ) for selected stations in the area of the best developed frost-heaved bedrock features in Canada *

\begin{tabular}{lcr}
\hline \multicolumn{1}{c}{ Station } & Freezing index Thawing index \\
\hline A- Northern Canada & & \\
Baker Lake & 5172 & 874 \\
Cambridge Bay & 5902 & 583 \\
Chesterfield Inlet & 4909 & 734 \\
Churchill & 3825 & 1157 \\
Churchill (airport) & 3721 & 1128 \\
Ennadai Lake & 4496 & 1085 \\
Spence Bay & 6050 & 539 \\
Yellowknife (airport) & 3614 & 1667 \\
& & \\
B- Northern Québec-Labrador: & & 1168 \\
Fort-Chimo & 3052 & 1447 \\
Fort-George & 2577 & 1490 \\
Gagnon & 2342 & 882 \\
Inoucdjouac & 3379 & 1288 \\
Knob Lake (Schefferville) & 2854 & 545 \\
Koartak & 3072 & 1447 \\
Nitchequon & 2745 & 1213 \\
Poste-de-la-Baleine & 2759 & 1354 \\
Wabush & 2604 & \\
\hline
\end{tabular}

* Data from BOYD (1973).

and conical mounds up to 2-3 $\mathrm{m}$ high and $15 \mathrm{~m}$ in diameter could survive for at least a few thousand years. The relict forms from Tasmania for example are thought to date back to the last glacial interval (CAINE, 1983).

Because several relict and non-active features coexist with active forms within present day permafrost regions, it is often difficult to discriminate the true relict features from recently non-active ones. At Churchill (Manitoba) for example, most frost-heaved bedrock features are considered relict (FRENCH and GILBERT, 1982). It is likely that a large percentage of the non-active forms from the numerous localities in Québec are also relict features developed during the colder periods of the Holocene. According to PAYETTE (1980), at least 5 colder periods have existed in northern Québec over the last 3000 years.

Problems of dating frost-heaved bedrock features arise from the complexity of the environmental conditions and the absence of datable material. However, locally it is possible to obtain a maximum age by indirect means. For example, in the eastern Hudson Bay area, some frost-heaved blocks protrude through raised beaches of the former Tyrrell Sea. As the approximate age of the beaches is known from buried shells and driftwood, and also from the isostatic curve, a maximum age for the relict or non-active frost-heaved features can be postulated. Elsewhere, at Clearwater Lake, frost-heaved structures have developed in an area which was previously covered by peat. The peat is older than the heaved blocks, so a maximum age can be 
obtained by dating peat samples from the cover found at the surface of large heaved blocks.

\section{CONCLUSION}

In conclusion, it is suggested that frost-heaved bedrock features are more widespread than formerly thought. Although not really proved, they also appear to be valuable permafrost indicators and can therefore be added to the list of the "second order" permafrost indicators already in use (WASHBURN, 1976, 1979). Additional fieldwork and research are necessary to obtain a more accurate knowledge of the exact geographical distribution of the sites of active frost-heaved bedrock features, and the variety of features present; in addition, special effort should be made to obtain the pertinent climatic data for each of these sites. It is likely that permafrost is not really required for their development. However, these features occurring in the permafrost zones are obvious of such conditions.

\section{ACKNOWLEDGEMENTS}

The author gratefully acknowledges the assistance of Peter B. Clibbon, Université Laval, Québec, in reviewing the English text. R.F. Black and O.J. Ferrians reviewed the manuscript submitted for the Fourth International Conference on Permafrost and Nel Caine, Institute of Arctic and Alpine Research (Colorado) revised the final copy. Their comments and suggestions were greatly appreciated. This research work has been parlty supported by financial aid from the National Research Council of Canada (NSERC), Ottawa, and Centre d'Études Nordiques, Université Laval, Québec.

\section{REFERENCES}

BLACK, R.F. (1976): Features indicative of permafrost, Annual Review of Earth and Planetary Sciences, vol. 4, p. 75-94.

BOURNÉRIAS, M. (1972): Pyramides rocheuses d'éjection en milieu périglaciaire, Puvirnituq, Nouveau-Québec, Revue de Géographie de Montréal, vol. 26, p. 214-219.

BOYD, D.W. (1973): Normal freezing and thawing degree-days for Canada, 1931-1960, Downsview, Environnement Canada, Atmospheric Environment, Report CLI-4-73, 38 p.

BROWN, R.J.E. (1969) : Factors influencing discontinuous permafrost in Canada, in Péwé, T.L., ed., The Periglacial Environment, Past and Present, Montréal, McGill-Queen's University Press, p. 11-53.

(1973): Permafrost - Distribution and relation to environmental factors in the Hudson Bay Lowlands, Proceedings of the Symposium on the Physical Environment of the Hudson Bay Lowlands, University of Guelph (Ontario), p. 35-68.

- (1975): Permafrost investigations in Québec and Newfoundland (Labrador), Ottawa, National Research Council, Division of Building Research, Technical Paper No. 449, $99 \mathrm{p}$.

- (1978) : Permafrost map, in Hydrological Atlas of Canada, Ottawa, Environment Canada, Inland Water Directorate, Plate 32.
(1979): Permafrost distribution in the southern part of the discontinuous zone in Québec and Labrador, Géographie physique et Quaternaire, vol. 33, p. 279-289.

BROWN, R.J.E. and PÉWÉ, T.L. (1973) : Distribution of permafrost in North America and its relationship to the environment: a review, 1963-1973, in Permafrost - The North American contribution to the Second International Conference, Yakutsk; Washington, D.C., National Academy of Sciences, p. 71-100.

CAINE, N. (1983): The mountains of northeastern Tasmania: A study of alpine geomorphology, Rotterdam, Balkema, 200 p.

DERRUAU, M. (1958): Précis de géomorphologie, Paris, Masson, 2nd ed., 395 p. (cf. plate XVI-B).

DILABIO, R.N.W. (1978) : Occurrences of disrupted bedrock on the Goulburn Group, eastern District of Mackenzie, Geological Survey of Canada, Paper 78-1A, p. 499-500.

(1982) : Recognition of frost-heaved outcrops, Athabasca Basin, Saskatchewan, Geological Survey of Canada, Paper 82-1A, p. 432.

DIONNE, J.-C. (1978) : Formes et phénomènes périglaciaires en Jamésie, Québec subarctique, Géographie physique et Quaternaire, vol. 32, p. 187-247.

(1980): Champs de palses dans la région de BlancSablon, Annales de l'Association canadienne-française pour l'avancement des Sciences, vol. 47, p. 117.

(1981): Formes d'éjection périglaciaires dans le Bouclier laurentidien, Québec, Revue de Géomorphologie dynamique, vol. 30, p. 113-124.

DYKE, L. (1979): Bedrock heave in the central Canadian Arctic, Geological Survey of Canada, Paper 79-1A, p. 241-246.

(1981): Bedrock heave in the central Canadian Arctic, Geological Survey of Canada, Paper 81-1A, p. 157-167.

FRENCH, H.M. (1981): Periglacial phenomena near Churchill, Manitoba, in The Hudson-James Bay Symposium, University of Guelph, Ontario, Abstracts p. 6.

FRENCH, H. M. and GILBERT, R. (1982): Periglacial phenomena near Churchill, Manitoba, Naturaliste canadien, vol. 109, p. 433-444.

GANGLOFF, P., GRAY, J.T. and HILLAIRE-MARCEL, C. (1976): Reconnaissance géomorphologique sur la côte ouest de la baie d'Ungava, Revue de Géographie de Montréal, vol. 30, p. 339-348 (cf. p. 342).

GODARD, A. (1979): Reconnaissance dans l'extrémité nord du Labrador et du Nouveau-Québec. Contribution à l'étude géomorphologique des socles des milieux froids, Revue de Géomorphologie dynamique, vol. 28, p. 125-142 (cf. p. 134 and 142).

HARRIS, S.A. (1981): Distribution of zonal permafrost landforms with freezing and thawing indices, Erdkunde, vol. 35, p. 81-90.

HILLAIRE-MARCEL, C. (1979): Les mers du post-glaciaire du Québec, Paris, Université Pierre et Marie-Curie, Doct. thesis unpubl., 293 p. (cf. Plate 17, fig. 7-8).

HOGBOM, B. (1910): Einige Illustrationen zu den geologischen Wirkungen des Frostes auf Spitsbergen, Uppsala University, Geological Institute Bulletin, No. 9, p. 41-59 (cf. p. 42-43).

- (1914): Uber die geologische Bedentung des Frostes, Uppasala University, Geological Institute Bulletin, No. 12, p. 257-289 (cf. p. 274-277). 
IVES, J.D. (1979) : A proposed history of permafrost development in Labrador-Ungava, Géographie physique et Quaternaire, vol. 33, p. 233-244.

KERR, J.W. (1977): Frost and glacially deformed bedrock on Somerset Island, Northwest Territories, Geological Survey of Canada, Paper 77-1C, p. 75-77.

KRANCK, E.H. (1951): On the geology of the east coast of Hudson Bay and James Bay, Acta Geographica, vol. 11, No. 2, 71 p. (cf. p. 37-38).

LAURIOL, B., GRAY, J.T. and PILON, J. (1982): Émersion marine (baie d'Ungava), Geos, vol. 11, No. 4, p. 5-8.

LAVERDIĖRE, C. and GUIMONT, P. (1981): Géographie physique de la Grande île, littoral québécois de la mer d'Hudson, Montréal, Société de Développement, de la Baie-James, Rapport, 81 p. (cf. p. 75 and fig. 33-34).

LEBRUN, C. (1983) : Géomorphologie des soulèvements et des évidements rocheux périglaciaires dans la presqu'île des Manitounouc, Québec, Université Laval, Dép. de Géographie, M.A. thesis (unpubl.).

MALAURIE, J. (1968): Thèmes de recherche géomorphologique dans le nord-ouest du Groenland, Paris, Éditions du CNRS, Mémoires et Documents, no hors-série, 495 p. (ct. photo 18).

PAYETTE, S. (1978): Les buttes rocheuses d'origine périglaciaire au Nouveau-Québec, Géographie physique et Quaternaire, vol. 32, p. 369-374.

(1980): Fire history at the treeline in northern Québec: a paleo-climatic tool, in Proceedings of the Fire History Workshop, Tucson, p. 126-131.
PAYETTE, S. and MORRISSET, P. (1974): The soils of Sleeper Islands, Hudson Bay, N.W.T., Canada, Soil Science, vol. 117, p. 352-368 (cf. p. 355).

SÉGUIN, M. and ALLARD, M. (1983) : La répartition du pergélisol dans la région du détroit de Manitounuk, côte est de la mer d'Hudson, Canadian Journal of Earth Science, vol. 20 (in press).

THOM, G. (1978): Disruption of bedrock by the growth and collapse of ice lenses, Journal of Glaciology, vol. 20, p. 571575 .

TYRRELL, J.B. (1897): Report on the Doobaunt, Kazan and Furguson Rivers and the northwest coast of Hudson Bay, Geological Survey of Canada, Annual Report-1896, v. IX, Part F, 218 p. (cf. p. 84 and plate VII).

WASHBURN, A.L. (1969): Weathering, frost action, and patterned ground in the Mesters vig District, northeast Greenland, Meddelelser om Gronland, vol. 176, No. 4, 303 p. (cf. p. 51-52).

, ed. (1976): Periglacial indicators of permafrost, Quaternary Research, vol. 6, No. 1, 126 p.

(1979): Geocryology. A survey of periglacial processes and environments, London, Edward Arnold, 406 p. (cf. p. 80).

YARDLEY, D.H. (1951) : Frost-thrusting in the Northwest Territories, Journal of Geology, vol. 59, p. 65-69.

ZOLTAI, S.C. (1971): Southern limit of permafrost features in peat landforms, Manitoba and Saskatchewan, Geological Association of Canada, Special Paper No. 9, p. 305-310.

(1972): Palsas and peat plateaus in central Manitoba and Saskatchewan Canadian Journal of Forest Research, vol. 2, p. 291-302. 